\title{
EXPLOTACIÓN ECONÓMICA Y FRONTERAS POLÍTICAS: DIFERENCIAS ENTRE EL MODELO IBÉRICO Y EL ROMANO EN EL LÍMITE ENTRE LA ALTA ANDALUCÍA Y EL SURESTE ${ }^{1}$
}

\author{
POR \\ TERESA CHAPA BRUNET y VICTORINO MAYORAL HERRERA \\ Departamento de Prehistoria. Universidad Complutense de Madrid
}

\section{RESUMEN}

El trabajo aquí presentado pretende mostrar la importancia de la escala regional en el estudio de procesos de cambio de carácter general. El ejemplo se centra en el Valle del Guadiana Menor (Jaén), una zona de enlace entre la Alta Andalucía, las altiplanicies granadinas y el Sureste Peninsular. Mediante una visión diacrónica desde el Ibérico Pleno al cambio de Era se aprecia cómo las transformaciones en la estrategia política, social y económica, condicionan los sistemas de poblamiento, explotación y distribución de los productos.

\section{ABSTRACT}

The importance of locating generalised accounts of change in their regional contexts is illustrated by a study of the basin of the Guadiana Menor (Jaén). This forms a corridor between Upper Andalusia on the one hand and the Highlands of Granada and the S.E. of the Peninsula on the other. Its focus is how over time - from the Middle Iberian Period to the end of the 1st century $\mathrm{BC}$ - changes in political, social, and economic dynamics affect settlement patterns and the exploitation and distribution of resources.

El área de la Alta Andalucía ha sido objeto en los últimos años de un intenso trabajo arqueológico, que ha conseguido definir los procesos de formación y desarrollo de la Cultura Ibérica (Ruiz y Molinos, 1993). Menos conocidos son, sin embargo, los cambios que se producen con la llegada de cartagineses y romanos, que desembocarán en la formación de una nueva sociedad en el marco del Imperio Romano. En el debate actual sobre este proceso de transformación, la propia crisis del término "romanización" expresa la superación de posturas antagónicas respecto al papel atribuido a indígenas y foráneos. Con todo, este consenso sobre la complejidad y lentitud del cambio puede en ocasio-

1 Este trabajo se encuadra en el Proyecto de Investigación de la DGICYT PB95/0375: La Sociedad Ibérica en el Sureste Peninsular: una perspectiva espacial. nes enfocarse limitándose al análisis externo de manifestaciones culturales.
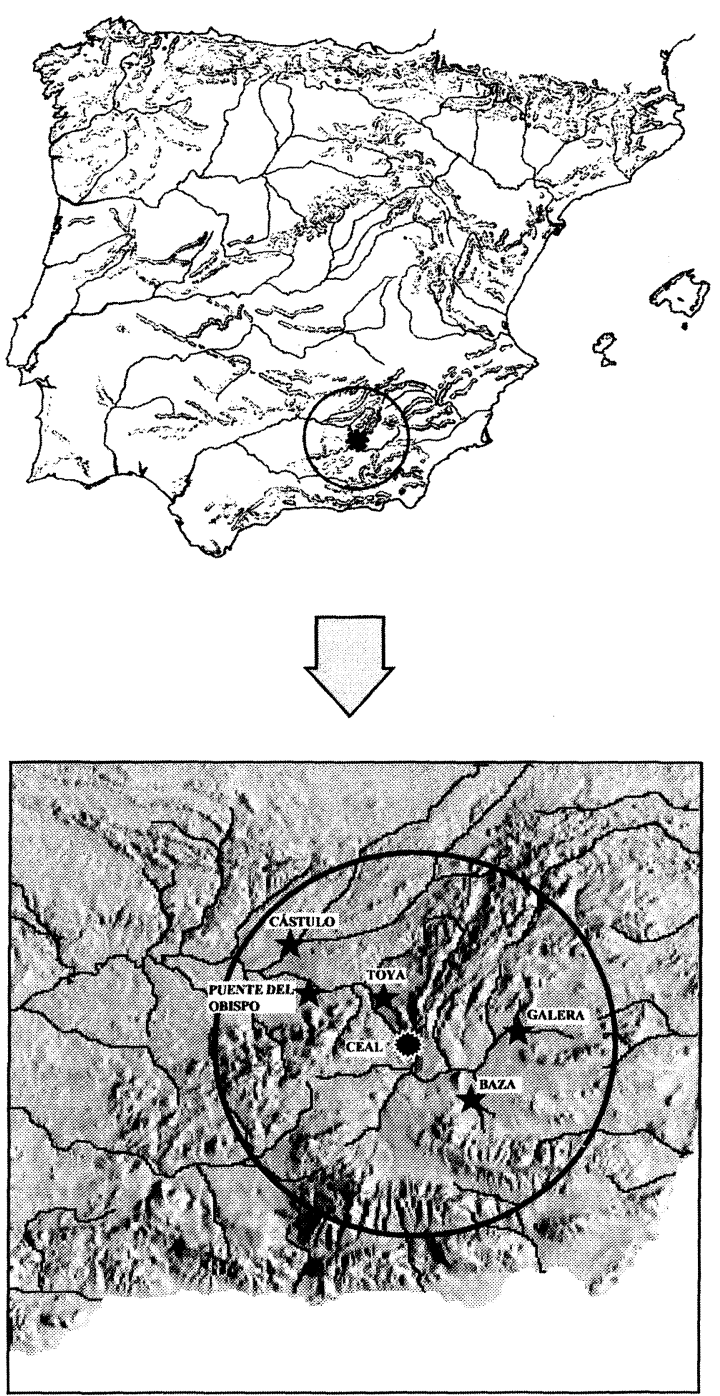

Fig. 1.-Localización de los principales yacimientos ibéricos vinculados al Guadiana Menor. 


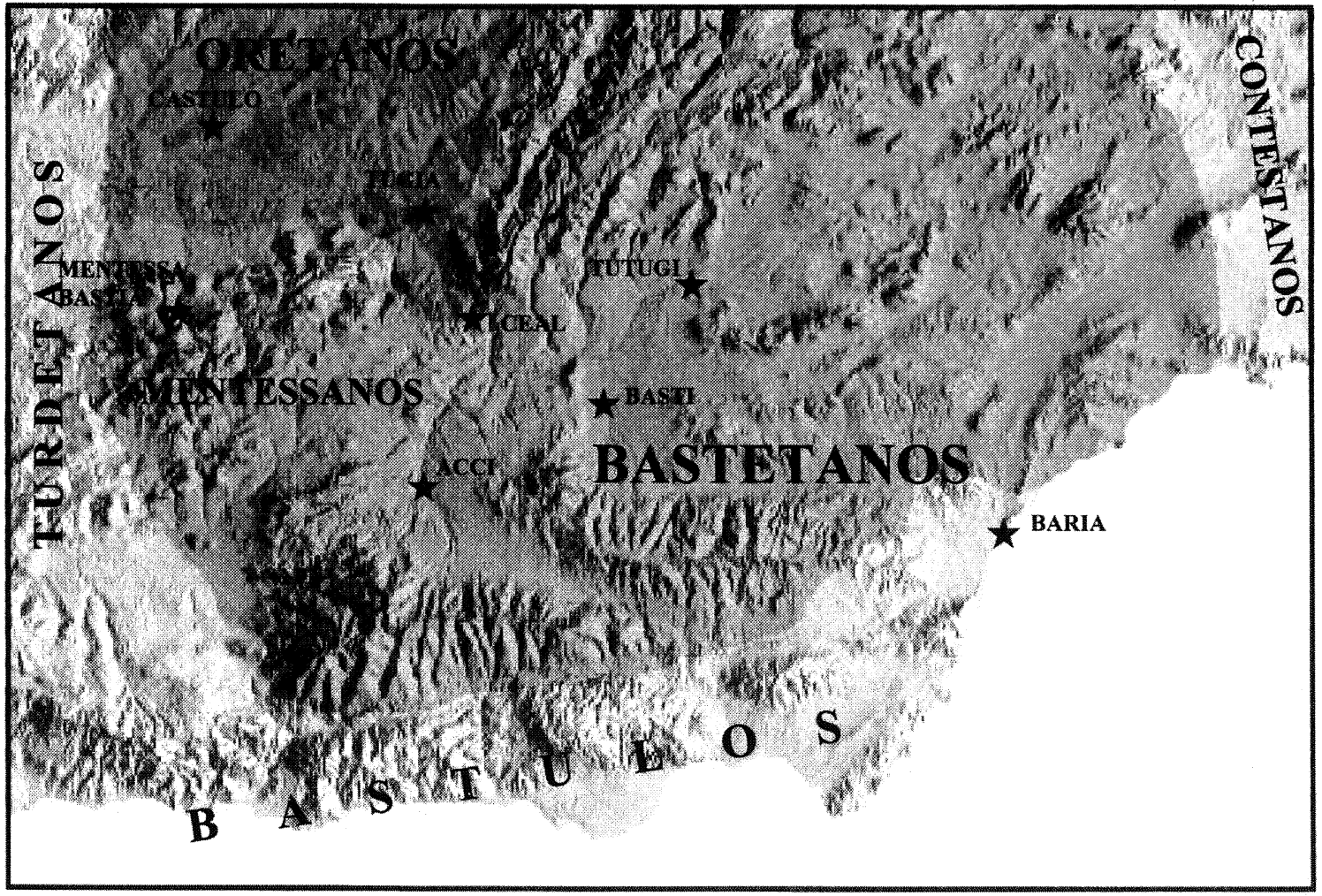

Fig. 2.-Distribución de los grupos étnicos ibéricos de Andalucía Oriental.

Esto nos conduce inevitablemente a una visión del proceso de «romanización» no como una contraposición entre culturas, en un plano horizontal, sino como una compleja red de tensiones en el seno de ambas sociedades, la ibérica y la romana. Caracterizará en buena medida a cada una de ellas, así como a la que ha de surgir de su contacto, la estructura de sus relaciones de dependencia, es decir, la forma en que las clases propietarias extraen del resto de la población los excedentes necesarios para asegurar su reproducción y mantenimiento en el poder. Como expresa contundentemente D. Plácido, «Lo demás son los reflejos, en los planos institucionales, religiosos, militares, de todos estos procesos (...) capaces de imponer una visión deformada sobre las realidades de fondo» (1996: 201).

Queremos insistir aquí en la idea de que, en esta situación transicional, las elites locales van a jugar un papel clave ya que, para mantener sus privilegios y su dominio de la tierra, se convertirán en agentes activos de la implantación de la organización romana.

El estudio de este proceso se aprecia mejor mediante un análisis diacrónico de zonas concretas, en las que existen amplias secuencias que permiten di- ferenciar unas etapas con respecto a otras en un mismo ambiente geográfico y cultural. El área del Guadiana Menor, en el ámbito comprendido entre su desembocadura en el Guadalquivir y las altiplanicies granadinas, es un espacio adecuado para este estudio, ya que se trata de una zona con unas condiciones geográficas muy específicas, que limitan significativamente los sistemas de subsistencia, y en la que por tanto influirán de manera acusada las sucesivas administraciones ibéricas y romanas.

El río Guadiana Menor actúa en época ibérica como un pasillo crucial en las comunicaciones entre el eje de Cástulo-Toya y las rutas que se dirigen al Sureste y Sur peninsular. El carácter de área fronteriza dentro de un mapa político fragmentado en el que aparecen, entre otros, bastetanos, oretanos, mentesanos y turdetanos, hace que los oppida principales, como Tugia, promocionen el control de las rutas de paso, por su doble interés económico y estratégico. En apoyo de las mismas surgen enclaves, como Castellones de Ceal, en los que una pequeña población ligada a la explotación intensiva de la vega fluvial sirve como enlace en el difícil tránsito hacia y desde el Guadalquivir. El desmantelamiento de los territorios étnicos ibéricos y su sustitución 
por la administración romana va a transformar de una forma definitiva el diseño de las comunicaciones y las formas de explotación de la tierra, dejando obsoleto el modelo anterior y llevando a ciertas poblaciones como la antes citada a la desaparición.

Estos cambios, sin embargo, no se producirán repentinamente, sino que serán fruto de un largo proceso de reajustes que no concluirá en esta zona hasta comienzos del s. I a.C. Mientras tanto, se mantendrán en cierta medida las estructuras económicas previas, dominadas y gestionadas por las elites ibéricas, que se acercarán en lo posible al modelo romano, intentando no perder su posición de privilegio. La revisión de las principales características de esta zona a través de los diferentes periodos nos permitirá apreciar mejor la naturaleza de estas importantes transformaciones.

\section{LA EVOLUCIÓN DEL TERRITORIO EN ÉPOCA IBÉRICA: S. V-III A.C.}

Durante el s. v a.C. asistimos al proceso de configuración de las comunidades ibéricas que perdurarán en Andalucía oriental hasta época romana. Las antiguas comunidades han pasado a constituir núcleos importantes en los que la producción especializada es algo habitual, desarrollándose el uso del torno en la manufactura cerámica (Ruiz Rodríguez, 1978: 260). La incorporación del hierro al armamento y al utillaje agrícola se generaliza progresivamente, permitiendo una considerable intensificación productiva (Ruiz Rodríguez et al., 1983: 241 ). Todo ello supone el desarrollo de una élite gestora que intenta establecer las reglas de funcionamiento interno, así como las relaciones entre grupos vecinos. Esto implica una afirmación de los rasgos propios a través de elementos distintivos (Almagro Gorbea, 1982: 255), así como el establecimiento de normas internas de jerarquización social que afectan a la totalidad de los individuos que integran el grupo (Ruiz Rodríguez et al., 1992: 416).

En un primer momento, centrado en el s. v a.C., parece que la unidad básica que concentra a la totalidad de la población, incluidos los productores agrícolas, es el oppidum, asentamiento fortificado que en Andalucía oriental oscila entre las 44 ha de Cástulo como enclave principal, a las 16 ha de Villargordo o las 5/6 ha de Puente Tablas (Almagro Gorbea, 1987: 24-25). La entidad de cada uno de ellos está en relación directa con la producción de recursos especializados o con su vinculación a tierras especialmente fértiles, tanto de secano como de regadío (Molinos et al, 1994: 137). Se crea así un modelo reticular que encaja bien con la explotación de ganado vacuno y ovino y de cereal de secano característica de la Campiña de Jaén (Ruiz Rodríguez y Molinos Molinos, 1993b: 557).

Sin embargo, en la zona oriental vinculada al Guadiana Menor, las características del terreno obligan a desarrollar estrategias diferentes, basadas en la cabaña de ovinos y caprinos y en el aprovechamiento intensivo de las márgenes de los ríos mediante irrigación, básicamente natural (Chapa, 1992: 322). Esto proporciona un modelo longitudinal en el que los cauces de los ríos son un recurso crítico, a la vez que las únicas vías posibles de conexión entre diferentes asentamientos y territorios. En este sentido, los vados se convierten necesariamente en puntos clave de control para el desplazamiento a través de espacios fuertemente constreñidos por el relieve.

Las características específicas de esta zona de Jaén/Granada parecen tener su expresión material en algunos elementos distintivos, que en gran medida se relacionan con sus elites rectoras. Así, el empleo de cámaras funerarias como sepultura, y la introducción en ellas de cajas de piedra como contenedores de las cenizas de los difuntos, ha sido uno de los rasgos considerados como específicos de esta zona frente a las áreas vecinas (Almagro Gorbea, 1982). Asimismo, el abundante uso a comienzos del s. IV a.C. de las crateras áticas como recipientes cinerarios puede unirse a la enumeración de estos elementos distintivos (Olmos, 1982). La distribución de estas estructuras y objetos se centra precisamente en el área del Guadiana Menor, documentándose en yacimientos como Toya, Galera, Baza y Castellones de Ceal.

La distribución de los citados asentamientos nos permite comprender en gran medida el diseño del poblamiento a escala regional, así como valorar el papel de los puntos de apoyo intermedios, necesarios cuando la ruta de conexión atraviesa zonas de tránsito complicado. El oppidum de Toya (antigua Tugia) presenta un alto potencial económico, gracias a las posibilidades de combinar amplias áreas de secano con fértiles huertas vecinas a los ríos (Chapa et al., 1984). Por otra parte, su posición estratégica en la confluencia del Guadiana Menor con el Guadalquivir y en la ruta de paso hacia el centro minero de Cástulo refuerza esta situación de poder. Ello permite comprender la envergadura de sus construcciones funerarias, entre las que destaca una cámara de sillería con tres naves en la que se guardaron diversas cremaciones pertenecientes al parecer a miembros de una misma dinastía (Cabré, 1925; Madrigal, 1997). 
A su vez, Baza (Basti) y Galera (Tutugi) también cumplieron este papel preeminente en sus respectivos territorios de influencia, destacándose por la complejidad de sus construcciones y ajuares funerarios. Entre ellos abundan los materiales importados (Blázquez, 1978: 237) y los objetos de lujo de producción local, incluyendo la conocida dama sedente esculpida en piedra que hacía las funciones de urna en la tumba 155 de Baza (Presedo, 1982: 210). Ambos asentamientos se sitúan en el control de dos importantes rutas (Adroher Auroux, 1987-88: 192). Baza domina las llanuras que, en dirección este a oeste, actúan como distribuidoras en los caminos que comunican la costa con el interior. Galera se emplaza en una importante ruta ganadera tradicional que enlaza el área de Murcia con la Alta Andalucía.

La vía más rápida para la comunicación entre estos dos centros y Toya es el Guadiana Menor, uno de los escasos corredores que abren una vía de penetración hacia la cabecera del Guadalquivir. Resulta necesario, por tanto, jalonar esta difícil travesía con puntos de apoyo (Blanco, 1959). A esta tipología puede adscribirse el poblado de Castellones de Ceal, con apenas 1,2 ha. Domina un vado del río y sus dimensiones reducidas permiten que su subsistencia inmediata quede cubierta con la explotación de la vega del río adyacente al poblado (Chapa et al., 1984: 233).

Todos estas unidades de población pertenecen a la misma agrupación étnica, que las fuentes escritas nos darán más tarde a conocer como bastetani, extendidos por una amplia zona del Sureste peninsular. La situación al norte del Guadalquivir de los oretani nos indica que Tugia fue una ciudad fronteriza, constituyendo un puesto avanzado de los bastetanos en las proximidades del centro minero de Cástulo (Pastor et al., 1992: 123-125). Esto resulta fundamental para entender la importancia estratégica de Toya y su influencia en el diseño de su territorio inmediato. A finales del s. V a.C. el tráfico comercial entre la Alta Andalucía y la costa del sur y Sureste va a potenciar la ruta del Guadiana Menor con la fundación de asentamientos como Castellones de Ceal, cuyo primer hábitat del s. VI a.C. había sido abandonado (Chapa et al., e.p.). Sus materiales y estructuras, tanto de hábitat como funerarias, revelan una clara identidad con las recuperadas en Toya (Pereira, 1989: 156), por lo que parece razonable pensar que fue este centro el que asegura el control de la ruta mediante puntos subsidiarios de apoyo.

El modelo propuesto supone que a finales del s. V a.C. los núcleos de importancia como Toya ejercían un control político que no se limitaba al espa- cio de producción explotado por la población residente en el oppidum, sino que se proyectaba sobre otros pequeños puntos de población, asegurando un territorio de influencia extendido en apoyo de las relaciones comerciales y de la ampliación de los recursos agrícolas y ganaderos (Molinos et al. e.p.). Esto supone para las jerarquías dominantes un doble acceso al control de recursos y riquezas. Por una parte, en una primera fase el oppidum ha establecido su orden de dominio sobre el territorio inmediato, consolidando así un sistema de dependencia basado fundamentalmente en la propiedad de la tierra y del ganado (Ruiz y Molinos, 1993a: 266). En un segundo momento se abre otra nueva opción para la acumulación de riqueza y poder. Es la vinculada al control del comercio y de la exportación de las materias primas requeridas por el mercado mediterráneo (Cabrera, 1994: 95). Esto ofrece a Toya la oportunidad de permitir el trasiego por una ruta difícil, a la vez que obtener beneficios de aquellos que transiten por ella.

Resulta evidente que estamos ante una situación de jerarquización, tanto a nivel interno del oppidum como a escala regional, ya que el poder efectivo se ha extendido mediante asentamientos secundarios a lo largo de un territorio cuyo fin primordial no es únicamente la producción, sino también el control de las rutas de paso. Esto otorga a algunos de los pequeños asentamientos un valor económico diferente a los centros mayores ya que, si bien se sitúan en lugares donde sea posible una economía autosuficiente (Chapa et al., 1984), en ningún caso existe la oportunidad de generar excedentes. La presencia, sin embargo, de un alto número de productos especializados, como objetos de lujo - joyería, bronces- productos importados - vasos áticos, vidrios, etc. - o armas de hierro, hace pensar que su contacto con el centro principal fue muy estrecho. El área de influencia de los asentamientos de importancia se irá extendiendo a través de estos núcleos subsidiarios, creando un sistema de relaciones que será de gran relevancia en la etapa inmediatamente posterior, cuando los romanos y cartagineses interaccionen con la estructura indígena previa.

En el s. III a.C la inestabilidad política y económica va a ser la nota dominante, y de hecho en las fuentes escritas Toya aparece alternativamente como oppidum oretano o bastetano. En esta situación de conflicto la presencia cartaginesa es sin duda relevante, ya que desarrolla un gran esfuerzo por controlar directamente los recursos ofrecidos por la Península Ibérica. No obstante, este expansionismo bárcida se apoyó en las clases dirigentes locales, lo que les proporcionó grandes beneficios. Este es el 


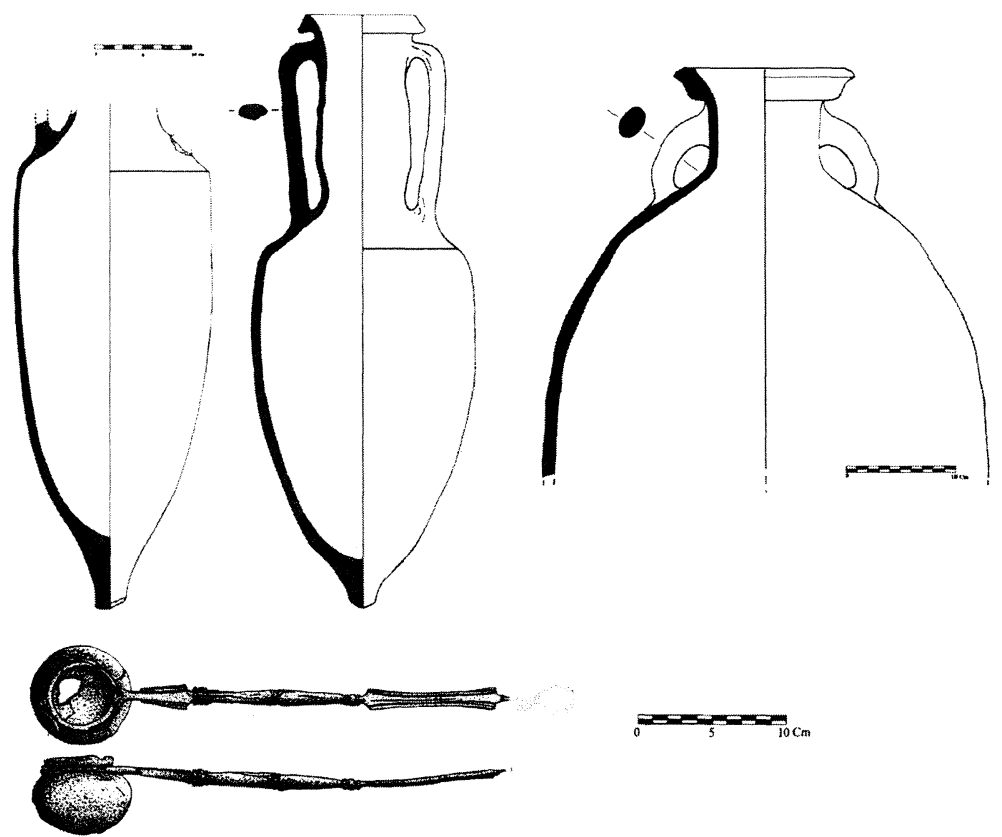

Fig. 3.- Importaciones romanas correspondientes a la fase final del poblado de Los Castellones de Ceal (Hinojares, Jaén).

caso bien conocido de Cástulo, un centro territorial importante de rico potencial minero, en donde los jefes cartagineses recurren a la práctica de las alianzas matrimoniales (Blázquez y García Gelabert, 1994: 56). Esto indica que en las altas esferas la política se está moviendo en el campo del pacto y de la negociación. La vinculación de Cástulo sería recompensada por el apoyo cartaginés a los planes oretanos de ampliar su dominio hacia el sur del Guadalquivir, llegando a englobar Toya como ciudad oretana. En cualquier caso, todo indica que la dinámica interna hacia la que conducen estos cambios durante la etapa siguiente no va a favorecer en absoluto una rápida disolución de las estructuras de poder ibéricas, y sí en cambio el mantenimiento de una posición de fuerza por parte de sus clases propietarias de cara a la dominación impuesta por Roma.

\section{Los SIGLOS II-I A.C.}

1. Presencia romana y continuidad del esquema económico ibérico

Con la conquista romana las regiones a un lado y otro del corredor del Guadiana Menor quedan por primera vez englobadas en una sola entidad territorial. No obstante, el valor estratégico de la ruta se mantiene aún hasta comienzos del siglo I a.C. Ello es en gran medida debido a la gran facilidad de acceso desde esta zona a la región minera de Cástulo, de gran interés geoeconómico para Roma.

Durante el período que estamos considerando, las riquezas mineras de la Península pertenecen al Estado romano, el cual arrienda a particulares su explotación y distribución. Las empresas que se constituyen para el aprovechamiento de estas concesiones varían en la envergadura de su capital y el número y estatus jurídico de sus componentes.

Para los distritos mineros del Sureste y Sierra Morena, el análisis de las inscripciones de los lingotes de plomo procedentes de las minas nos permite conocer la diversidad de estas organizaciones ${ }^{2}$. Se documentan en primer lugar un gran número de pequeñas empresas individuales, la mayoría de las cuales están directamente relacionadas con el entorno de Cartagena. Siguen en cuanto a frecuencia las pequeñas y medianas sociedades ordinarias, algunas de las cuales llegan a adquirir gran importancia ${ }^{3} \mathrm{y}$ que estarían asentadas en la misma región.

En contraste, sólo contamos con una estampilla que haga alusión a este tipo de concesiones en Sie-

2 Para un estudio pormenorizado de estas piezas y sus implicaciones en la estructura de las explotaciones véase Domergue, 1965, 1966 y 1990: 253-277.

${ }^{3}$ Un ejemplo de ello son los Planii, de origen campano, que a inicios del siglo I a.C. explotan minas de plomo de la región de Cartagena. La distribución de esta producción generó grandes beneficios y alcanzaba los puertos de Sicilia y la Península Itálica (Domergue, 1965: 25). 
rra Morena. Serán sin embargo más frecuentes a finales de la república e inicios del imperio (Domergue 1990: 265). Por último, las grandes sociedades anónimas son las menos numerosas y tendrán como principales centros de actividad las zonas de Mazarrón y Sierra Morena, destacando su ausencia en las minas de Cartagena.

En las regiones mineras del Noreste, y sobre todo en el Sureste peninsular, esta actividad tendría un desarrollo inmediato a la conquista. Sin embargo, en Sierra Morena el aprovechamiento romano de la mayoría de las explotaciones no se inicia hasta finales del siglo II a.C. ${ }^{4} \mathrm{y}$, como acabamos de ver, sin evidencias de una afluencia de pequeños empresarios hasta épocas avanzadas. Estas fechas suponen por tanto un desfase que ha sido interpretado como una prueba de la inseguridad aún reinante en las conquistas del interior, unida a las dificultades técnicas que implicaría el mantenimiento de las explotaciones. Keay (1992: 289) retoma esta idea, planteando de un modo directo que las minas estarían aún en parte bajo control ibérico.

Queremos valorar aquí como factor a tener en cuenta la incapacidad, tantas veces mencionada, que tiene el Estado romano en este momento para imponer un control administrativo directo sobre el territorio. Esta circunstancia convertirá en práctica común el apoyo en las clases dirigentes locales, que ya anteriormente habían explotado las minas bajo el control cartaginés. Desde esta perspectiva cabe considerar esta intervención inicialmente limitada como indicador del mantenimiento de la posición ventajosa manifestada en la etapa anterior, es decir, como prueba de la capacidad de la aristecracia indígena para frenar el proceso de implantación de elementos itálicos y romanos en estas actividades económicas ${ }^{5}$.

${ }^{4}$ Domergue (1990: 183-184) distingue con claridad la existencia de estos dos momentos: una primera fase fechable a inicios del siglo il a.C. en la que el control minero se centraría principalmente en los distritos mineros del Sureste, mientras que en Sierra Morena la actividad romana hasta mediados de siglo se limitaría al ámbito más cercano a Cástulo, experimentando un momento de auge en la transición del II al I. Poblados mineros como el de La Loba (Blázquez, 198283: 37) o Valderepisa (Fernández Rodríguez y García Bueno, 1993: 38) ofrecen una cronología de entre finales del siglo II y la primera mitad del i a.C.

5 Chaves (1994: 116) expresa este parecer al afirmar que "no es desdeñable la idea de que, aún en las minas arrendadas a romanos o itálicos fuera no sólo aceptable, sino conveniente la participación de los habitantes del país" (la cursiva es nuestra). Por su parte Domergue (1990: 276) recoge testimonios literarios de la continuidad de la explotación de las minas por las poblaciones ibéricas. Una evidencia clara sobre la participación indígena en la administración de las minas sería el plomo con escritura ibérica hallado en Gádor (Almería), identificado por Gomez Moreno (1961: 919-922) y Maluquer (1968: 80-82) como un documento de contabili-
Aunque con el dudoso sustento de un pasaje de Livio $(28,20)$, se plantea la posibilidad de que Cástulo gozase de estatus de ciudad federada desde los momentos iniciales de la conquista ${ }^{6}$. El hecho de que una ciudad que había sido un importante foco de apoyo al dominio cartaginés cuente con la benevolencia romana en la nueva situación «no sólo refleja un papel dominante en el territorio (...) sino asimismo un control real de las riquezas que en él se generan y por él transcurren» ( Ruiz y Molinos 1988: 55).

\section{Moneda y administración local}

Almagro Gorbea, en su estudio iconográfico sobre la moneda con jinete y cabeza varonil de Hispania Citerior, resalta la posible intencionalidad política de estas imágenes como expresión ideológica de las elites rectoras de los oppida (1995: 62). En la Hispania meridional, el mantenimiento de un control político y económico por parte de la aristocracia ibérica parece evidenciarse a través del fenómeno de la acuñación de moneda de bronce. Importantes centros del alto Guadalquivir como Cástulo y Obulco emitieron gran cantidad de este numerario, empleando la escritura indígena en sus leyendas monetales. Cada vez cobra más fuerza la interpretación de estas emisiones como una iniciativa que corresponde a las ciudades y que sería empleada a escala territorial por los gobiernos locales.

Refiriéndose tanto a esta zona como al Medio y Bajo Guadalquivir, Keay (1992: 288-291) ha propuesto el funcionamiento de un circuito interno en el que los pequeños asentamientos rurales obtendrían de los oppida de mayor tamaño (que ejercen una función dominante) una retribución en moneda por su producción agrícola, base del pago en especie de la tributación impuesta por Roma. Esta misma moneda serviría a los habitantes de las poblaciones menores para adquirir bienes producidos o controlados por esos centros principales. De esta manera la vinculación de la tierra a la maquinaria de explotación romana fosilizaba y fortalecía las rela-

dad, y citado por González Román (1992: 161) como exponente del apoyo de los negotiatores itálicos en las infraestructuras ibéricas.

${ }^{6}$ Marín Díaz (1988: 31) recoge como dudoso este testimonio al considerar que la palabra empleada (fide) no puede considerarse equivalente al término foedus. De todos modos, la ciudad parece conservar su importancia como centro regional, y ya en época cesariana recibirá el status de municipio de derecho latino (Solana Sáinz, 1989: 94). De hecho, como señala García-Bellido (1982: 45) en este período de transición Cástulo, como capital de distrito minero experimentará un rápido desarrollo. 
ciones de dependencia creadas por la elite ibérica en fases anteriores en torno a la propiedad de la tierra.

Chaves (1994: 112) plantea algunas objeciones a esta propuesta, apuntando que las emisiones de la mayoría de las cecas consideradas por Keay son demasiado irregulares y de escaso volumen como para vincularse a la circulación del excedente agrícola. El uso de esta moneda se restringiría al pago de servicios a pequeña escala.

Esta idea ha sido resaltada en repetidas ocasiones por $M^{\mathrm{a}}$ Paz García-Bellido (1986: 13, 1993: 99100). Las acuñaciones no deben interpretarse como prueba de la existencia de una verdadera economía monetaria durante esta etapa, sino más bien de la necesidad de efectuar pagos a determinados colectivos en circunstancias muy concretas.

El caso de Cástulo es especialmente ilustrativo. La ciudad inicia sus emisiones antes de la conquista romana ${ }^{7}$. Ya a mediados del siglo il a.C., la emisión de series paralelas con escritura ibérica refleja la autonomía de que goza el gobierno local para el abastecimiento de la moneda necesaria para el pago de salarios en las minas ${ }^{8}$.

Al preservar así las clases dirigentes de la ciudad el protagonismo de Cástulo como cabeza administrativa del distrito minero, se estaría manteniendo un modelo económico en el que la circulación de la riqueza minera está en parte bajo control de una aristocracia local, que participa activamente en el proceso de cambio, conservándose por ello una estructura territorial aún basada en el modelo anterior de oppida y centros dependientes.

Dentro de este esquema juegan un papel igualmente relevante enclaves como Tugia, que como ya dijimos controla la comunicación entre el Guadalquivir y el Sureste con el apoyo de asentamientos menores. Uno de estos pequeños poblados es Castellones de Ceal. Los niveles de inicios del siglo I a.C. en dicho asentamiento ofrecen abundantes muestras de importaciones itálicas ${ }^{9}$ así como de

\footnotetext{
7 García-Bellido (1982: 142) caracteriza estas monedas como una respuesta a necesidades locales de explotación de las minas por indígenas y ante el estímulo de la presencia bárcida.

8 Según García-Bellido (1982: 156), las series con mano, con una distribución estrechamente vinculada a las zonas mineras, serían emitidas fuera de Cástulo pero bajo su supervisión, mientras que las monedas con creciente fueron acuñadas para otras necesidades de la ciudad.

9 Destaca en primer lugar la abundancia de fragmentos de ánforas grecoitálicas y Dressel IA, especialmente en el espacio A de la vivienda 1, un ámbito de almacenaje que contenía varias de estas piezas in situ y que sugiere una actividad de acumulación de excedentes (Mayoral, 1996: 239). Otra importación característica del período presente en Castellones es la vajilla de bronce (al menos dos cyathi y una jarra) . Es igualmente frecuente el hallazgo de cerámica campa-
}

otros ámbitos peninsulares ${ }^{10}$. $\mathrm{Al}$ mismo tiempo, dichas importaciones se asocian con tipos cerámicos de difusión restringida al entorno regional, que indican el mantenimiento de estrechas relaciones con Toya.

\section{Hacia la implantación del modelo municipal}

Este panorama se va a transformar substancialmente a lo largo del siglo I a.C. En esta etapa la Península se va a convertir en escenario destacado de las disputas políticas que marcan la crisis final de la República romana. Como consecuencia, la región sufre un periodo de grave inestabilidad, relacionable concretamente con las luchas entre Sertorio y el partido senatorial ${ }^{11}$. Las excavaciones en Castellones de Ceal han revelado cómo este enclave sufre por estas fechas un abandono repentino ${ }^{12}$, si bien nos parece aventurado por el momento relacionar el acontecimiento con acciones militares concretas ${ }^{13}$.

Creemos que este cambio se ha de relacionar con procesos de alcance más amplio a una escala regional. Anteriormente hemos sostenido que Castellones justifica en buena medida su existencia como punto de control de la ruta de acceso a la zona minera de Cástulo. Centraremos por tanto nuestra atención en los cambios operados en este ámbito por estas fechas.

Según M $^{a}$ Paz García-Bellido (1982: 163) con Sila el sistema de arrendamiento de las minas de Cástulo a societates publicanorum va a dar paso a una venta de las propias explotaciones a propieta-

niense. Elementos tipológicos romanos son además habituales en producciones comunes (morteros, cuencos, botellas...) de cuya procedencia poco podemos decir a falta de un análisis de sus pastas.

10 Asociado a las ánforas Dressel del espacio A se recuperó una jarrita de cerámica gris ampuritana. Se han recuperado además fragmentos, e incluso una pieza entera, de cerámica pintada levantina, un tipo de hallazgo que por otra parte se atestigua en algún ajuar funerario de Galera.

1 Según García Mora (1994: 279), el grueso de las operaciones militares desarrolladas en el Alto Guadalquivir se centraría en el control de los centros mineros por parte del bando sertoriano.

12 Así parece sugerirlo la gran cantidad y variedad de materiales hallados in situ en el interior de las habitaciones, junto con evidencias de incendio en parte de las estructuras.

${ }_{13}$ En su estudio sobre imitaciones de moneda fraccionaria romana, Marcos Alonso (1996: 210-211) señala la coincidencia en el tiempo de operaciones del conflicto sertoriano encuadrables en el Guadiana Menor y el contexto de abandono de Castellones de Ceal, del cual procede un semis de imitación de moneda oficial romana. En cualquier caso, se ha de valorar el hecho de que este abandono parece ser definitivo $y$, que pese al gran valor estratégico de este asentamiento, no se constata la reubicación de la población en un emplazamiento alternativo. 
rios particulares, si bien sobre esta idea no existe acuerdo unánime ${ }^{14}$. La aparición de moneda contramarcada, junto con nuevos hallazgos como los precintos de plomo, nos indica el surgimiento de "alguna modificación en cuanto al transporte y destinatario en la administración de las minas" (ibid.: 164). Siguiendo siempre a esta autora, el propio final de las emisiones paralelas con escritura indígena es un indicador de cómo la ciudad ya no supervisa directamente la extracción y distribución del plomo y la plata.

En un contexto de creciente presencia de elementos itálicos y romanos que emprenden actividades comerciales en la zona, el circuito de comercialización del mineral y el tráfico de mercancías en su conjunto experimentaría una pérdida del monopolio por parte de los oppida. La red de asentamientos creada por estos últimos para su control sufriría un colapso, del cual el abandono de Castellones puede ser una buena muestra.

Esto traerá como consecuencia el replanteamiento de las relaciones económicas y de promoción social entre las elites ibérica y romana, pero no supone el final, ni mucho menos, de las aspiraciones de mantenimiento en el poder de las primeras.

Como señala Chaves (1994 : 117) la numismática refleja un claro cambio de situación hacia los años 70 a.C. Los epígrafes que nombran a los magistrados monetales de las emisiones subsiguientes estarán ahora escritas en alfabeto latino y éstas adaptadas a la metrología romana. Esto nos proporciona algunas valiosas indicaciones sobre el mecanismo por el cual se reproduce la negociación de intereses entre las clases dirigentes. Empezando por la antroponimia, su estudio revela el origen itálico y romano de varios de los nomina, en algunos casos adscribibles a los principales linajes patricios cuyos miembros ejercieron magistraturas en Hispania. Antes que una presencia real de individuos de dicha procedencia en el gobierno castulonense, lo que reflejan estos datos es el establecimiento de lazos de patronazgo entre la aristocracia ibérica y la romana. Junto a estos nombres encontramos otros de origen ibérico ${ }^{15}$.

\footnotetext{
${ }^{14}$ Contra García-Bellido, Domergue (1990: 263, n. 20) sostiene que la explotación de las minas de Sierra Morena seguirá a cargo de societates publicanorum. Las siglas $S C$ no corresponderían a propiedades de una sociedad capitalista que ha adquirido la mina, sino a uno de los principales concesionarios del estado en la zona.

15 Gonzalez Román, entre otros, ha estudiado la latinización en la onomástica de la zona andaluza, ofreciendo ejemplos como el del gentilicio Cornelius de Cástulo y Obulco, presente en las magistraturas monetales y, por otro lado, asociado a cognomina de raíz indígena (1994: 146). Para una revisión detallada de los gentilicios romanos e itálicos véase Marín Díaz, 1988: 60-82.
}

Por otra parte, se ha de considerar el propio hecho de encontrar magistraturas ciudadanas en comunidades aún ajenas al modelo organizativo romano. No aparecen en el caso de Cástulo con alusión explícita al cargo desempeñado. En las monedas de Obulco, sin embargo, sí es clara la referencia a los aediles en fechas comprendidas entre la segunda mitad del siglo II y el siglo I a.C., no como testimonio de la reproducción de esta magistratura romana, sino más bien como imitación formal tras la que de facto se conservan fórmulas de poder indígenas (Marín Díaz, 1988: 147-149). Tenemos, en resumen, indicios de una toma de iniciativa por parte de la clase propietaria local en su adaptación a la nueva situación. Los gobiernos locales, con instituciones y procedimientos plenamente ibéricos, imitan el léxico, la forma y las titulaciones propias de la administración romana, considerados desde la perspectiva de estas clases dominantes como "más desarrollados y positivos para el buen gobierno de una civitas" (Rodríguez Neila 1995: 265; la cursiva es nuestra).

Así, la persistencia de instituciones políticas y sociales indígenas define una dualidad en la que se entremezcla la referencia formal a las magistraturas romanas con la realidad de la organización aristocrática que caracteriza a las elites locales ${ }^{16}$.

\section{Entre el cambio de Era y la época Flavia}

\section{La reestructuración provincial}

En el año 12 ó en el 7 a.C. (según autores), se realizan modificaciones sobre la división provincial que estableciera Augusto dos décadas antes. Esto provoca la anexión a la Tarraconense de un extenso territorio inicialmente adscrito a la Bética. La región que a partir de entonces va a pasar al control directo del emperador engloba tanto a Cástulo como a Toya, llegando hasta la barrera montañosa de de las cordilleras béticas. Esta anexión no tiene en cuenta la frontera preexistente entre los pueblos bastetano y oretano, aunque preserva los límites occidentales de ambos grupos. Bastetania queda así incorporada en conjunto a la Tarraconense, pero el corredor del Guadiana Menor pierde su carácter fronterizo.

16 Documentos como la inscripción de La Rambla (Lacort, Portillo y Stylow, 1986) revelan la existencia de estas instituciones de origen local, en este caso con carácter de comision o legación que representa de cara al exterior al gobierno local y que por tanto actuaría como interlocutor frente otros estados (Rodríguez Neila, 1993: 409). Al mismo tiempo, la proclamación de un gasto público nos introduce en las prácticas de munificencia propias de la vida municipal romana (ibid. 395). 


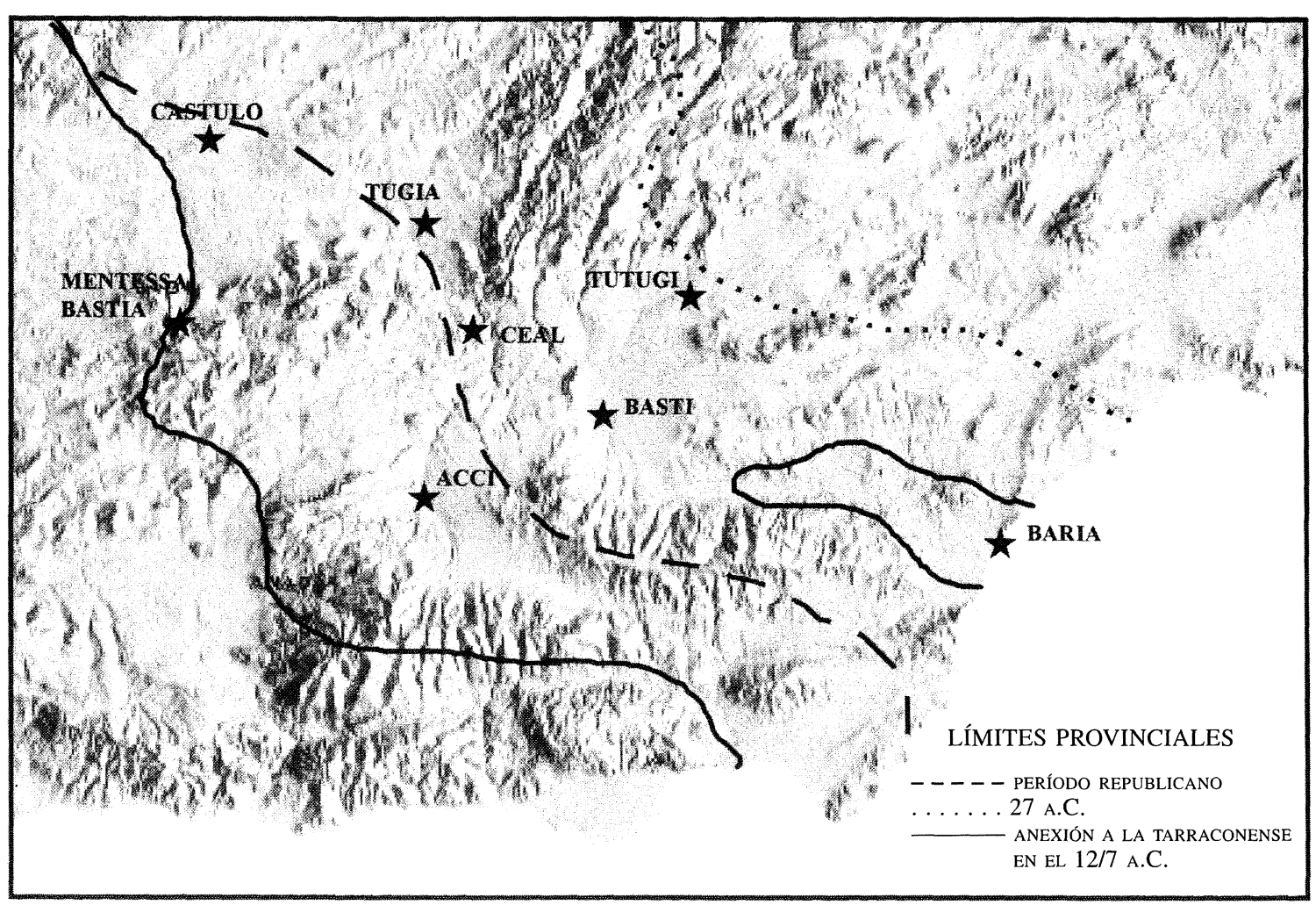

Fig. 4.-Límites provinciales romanos en el área del Sureste peninsular.

Tanto Toya ${ }^{17}$ como Cástulo perduran en esta etapa como importantes centros económicos y administrativos. Sabemos también de la continuidad de los importantes núcleos ibéricos de Basti y Tutugi en época romana ${ }^{18}$. Sin embargo, al mismo tiempo surgen nuevos centros que van a alterar el valor estratégico del corredor del Guadiana Menor. Quizá el cambio más significativo en este sentido sea la fun-

17 Tugia aparece recogida por Galsterer $(1971: 47,71)$ en el elenco de municipios a los que Vespasiano concederá el ius Latii. Excavaciones realizadas en el solar de la antigua ciudad (Mergelina, 1943-44) han proporcionado algunos elementos de arquitectura monumental, aunque en conjunto nuestro conocimiento del hábitat, tanto ibérico como romano, es muy limitado.

18 Basti permanece durante época imperial como ciudad estipendiaria. Excavaciones recientes (Marín Díaz et al. 1993-94: 323-333) han exhumado un conjunto de edificaciones de carácter público cuya primera fase se remontaría a inicios del siglo I d.C. y que cabe relacionar con el centro administrativo de la ciudad. En conjunto, estos trabajos han puesto de manifiesto una importante ocupación durante los siglos 1 y il d.C. En cuanto a Tutugi, las exploraciones de Cabré y Motos (1925: 9) dan testimonio de la existencia de un templo romano y posteriores excavaciones de Pellicer y Schüle (1962) documentan la continuidad entre la fase ibérica y la plenamente romana. La epigrafía no nos permitiría hablar de una comunidad independiente antes de mediados del siglo il d.C. (Perez Cruz, 1996-97: 1604). dación de Acci, que se convierte ahora en el gran centro político y económico de la Bastetania, siendo la única población de la depresión intrabética con status privilegiado ${ }^{19}$

El florecimiento de Acci está estrechamente relacionado con la ampliación hacia occidente de la Vía Augusta, que conectará el valle del Guadalquivir con el Oriente peninsular a través de las tierras altas de Granada. La consolidación de esta ruta supuso un desplazamiento hacia el Oeste de un eje de comunicaciones hasta entonces capitalizado por el itinerario del Guadiana Menor. En cuanto a sus infraestructuras, esta ampliación de la Vía Augusta parece haber sido concebida como una verdadera calzada para lograr una conexión rápida y estable, que seguiría básicamente la antigua Vía Heraklea. El acondicionamiento de ciertos tramos de esta vía facilitaría el tráfico rodado, rentabilizando notablemente el transporte. Sin embargo, las dificultades que presenta el cruce de las montañas béticas hubiera supuesto obras de gran envergadura que no llegaron a realizarse, de modo que en la práctica se pro-

19 González Román, 1992: 164. Un tratamiento detallado de la problemática de esta deductio puede hallarse en el mismo trabajo: 161-163. 


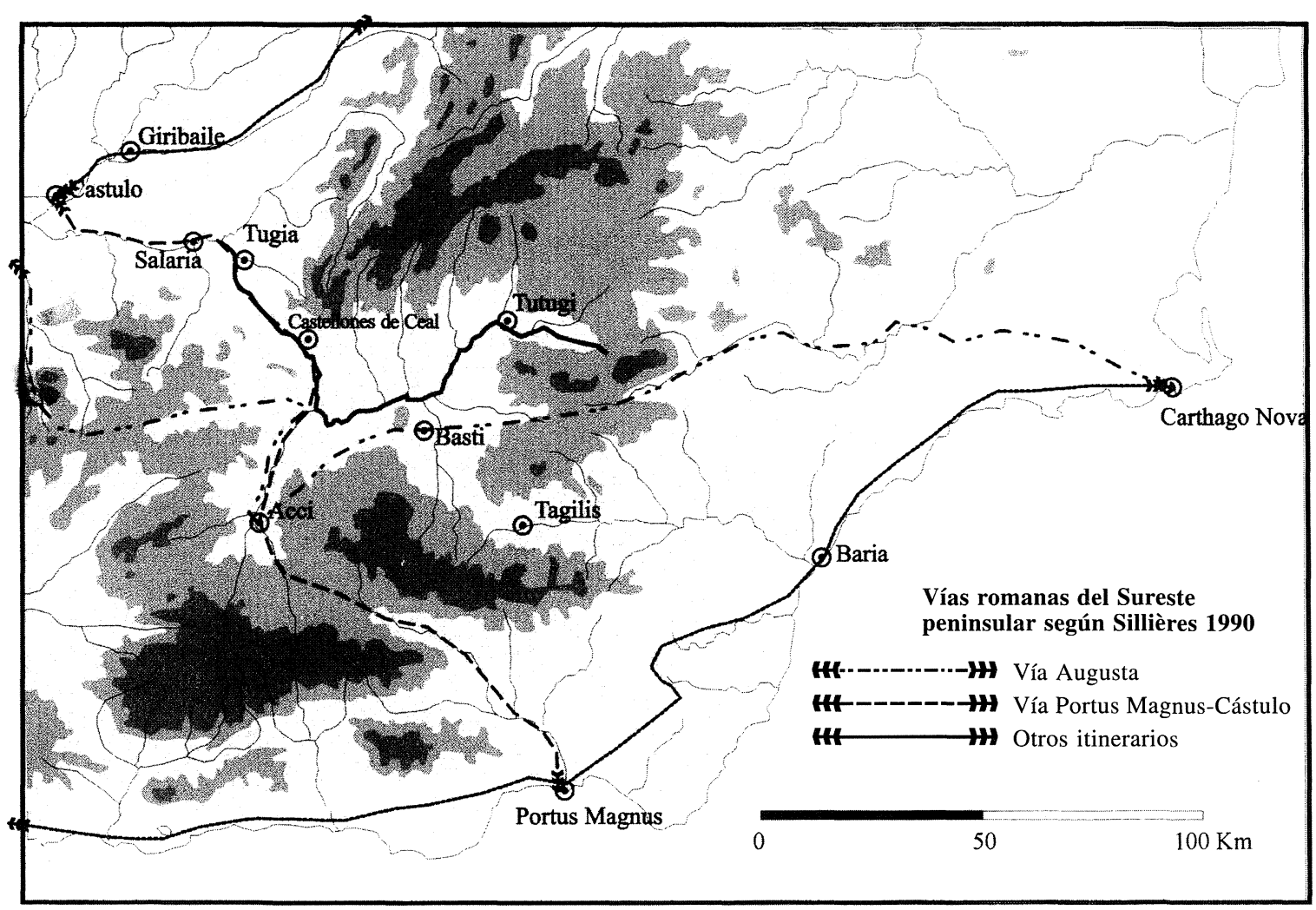

Fig. 5.-Vías romanas del Sureste de la Península Ibérica (según Sillières, 1990)

ducen escasas mejoras. En todo caso, el peso otorgado en este momento a la ruta que desciende al Guadalquivir siguiendo el Guadalbullón empieza a marcar el declive de otras vías más abruptas y estrechas, como la del Guadiana Menor.

Basándose en algunos documentos como el Edicto de Precios de Diocleciano ${ }^{20}$, Sillières (1990: 750-754) ha estimado el potencial de determinadas producciones de la Bética en función de la infraestructura viaria disponible, a fin de evaluar el significado económico de la misma. De su análisis se desprende que dentro de la racionalidad del comercio romano, una ruta que sólo permite como medio eficaz de transporte de mercancías el uso de bestias de carga, plantea costes demasiado altos. Estos sólo serían rentables para mercancías de alto valor, como los productos mineros, pese a tratarse de una mercancía de gran peso y volumen. El pasillo del Guadiana Menor es un buen ejemplo de ello. Una vez perdido su sentido estratégico, al englobarse en un territorio ampliado hacia occidente donde existen pasos más fáciles hacia el Alto Guadalquivir, sus

${ }^{20}$ No pretendemos extrapolar en absoluto estas figuras a épocas más antiguas. Nos interesan los contrastes entre unos precios y otros, más que los valores absolutos. dificultades orográficas, los problemas de tránsito en ciertas estaciones del año y la inexistencia de obras de mejora en época romana provocan un rápido eclipse de esta antigua vía. No obstante el recorrido sigue funcionando de forma residual como itinerario más corto entre el Alto Guadalquivir y el Sureste, y aparece reflejado en el Itinerario de Antonino como vía de conexión entre Cástulo y Portus Magnus (Sillières, 1990: 390-400). Existen por otra parte indicios de que algunos oppida Ibéricos situados en enclaves estratégicos respecto al río siguen en actividad ${ }^{21}$. Así las cosas, cabe suponer que la ruta del Guadiana Menor queda como un itinerario secundario .

2. La definición de un nuevo paisaje agrario y el nacimiento de una oligarquía urbana

En este contexto de marginación progresiva, el modelo económico de la zona seguirá basándose,

${ }^{21}$ P. Sillières ha identificado al menos dos sobre el terreno: Cerro Furuchú, dominando el curso del río Fardes, donde este autor ha reconocido cerámicas ibéricas, campaniense y sigillatas sudgálicas e hispánicas, y Baños de Alicún. 


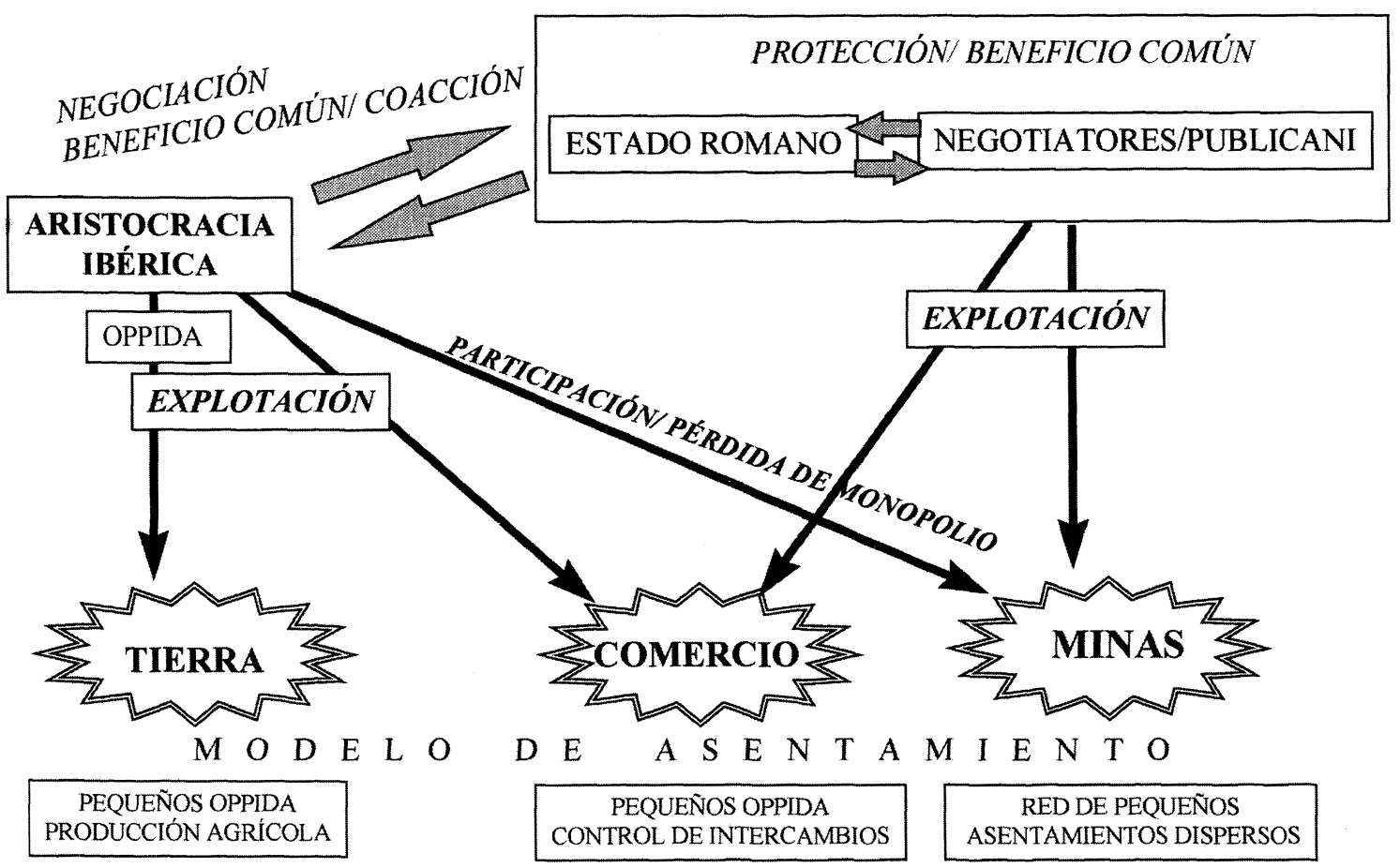

Fig. 6.-Conflictos de clase durante el proceso de implantación romana en el Alto Guadalquivir.

debido a las condiciones del propio terreno, en la agricultura intensiva y en el pastoreo de ovejas y, en buena medida, de cabras. Esto contrasta con otras zonas, como el curso medio y bajo Guadalquivir, donde a partir de la primera mitad del siglo I d.C. se aprecia una gran dinamización vinculada a cultivos extensivos como la vid y el olivo (Blázquez, 1985: 381-382). Semejante florecimiento no sólo debe relacionarse con las mayores posibilidades agrícolas de los suelos de la Campiña, sino también con la difusión de un modelo de agricultura de plantación con fines comerciales.

Por su parte, los sistemas de propiedad de la tierra en el Alto Guadalquivir van a sufrir grandes cambios en estos momentos. La implantación de núcleos regidos por el modelo organizativo romano ya había propiciado el inicio de las reparticiones de tierras, que van a dar lugar a la aparición de una pequeña-mediana propiedad ciudadana. Posteriormente, en tiempos de la dinastía flavia, se incrementará notablemente el número de comunidades que acceden al status municipal. Antiguos oppida estipendiarios como Tugia se incorporan de este modo al entramado social del Imperio. El nuevo régimen de tenencia de la tierra que así se generaliza dará lugar a una colonización del campo mediante asentamientos dispersos tipo villae.
Estudios sobre la zona inmediata de la alta Campiña (Castro López 1984 y 1989, Choclan y Castro 1987) han caracterizado este modelo como una economía campesina que asegura su estabilidad diversificando los cultivos y buscando la mayor autosuficiencia posible. La ciudad se convierte en centro de abastecimientos y de comercio a escala local y regional (Rodríguez Neila, 1993-94) tanto para colonos de origen itálico o romano como para los agricultores que han accedido a la condición de propietarios en tanto que miembros libres de la originaria comunidad ibérica ${ }^{22}$.

Las trazas arqueológicas de este movimiento colonizador parecen hacerse igualmente perceptibles en el entorno de Toya, donde las exploraciones de C. Fernández Chicarro $(1954,1957)$ han puesto en evidencia una considerable densidad del poblamiento rural romano (aún sin evaluar a falta de prospecciones sistemáticas). Se constata asimismo cómo estas explotaciones se extienden por el curso bajo del río Jandulilla (Lagunas et al., 1989), y el hallazgo de algunos asentamientos con fechas del siglo I sobre aterrazamientos de Guadiana Menor

${ }^{22}$ Esto plantea como importante cuestión a resolver el destino sufrido por las clases dependientes y no propietarias procedentes del extinto sistema de servidumbre. 
pueden indicarnos un fenómeno análogo en dicho valle ${ }^{23}$.

Las citadas transformaciones en la organización territorial cierran el círculo de la incorporación de la elite local a la estructura de poder implantada por Roma. El ordo decurional de las ciudades provinciales, compuesto por las principales familias de las clases propietarias, asegura el mantenimiento de un régimen oligárquico ${ }^{24}$. Pero ahora esta escala de promoción social queda abierta por su extremo más alto por la posibilidad de acceder a la elite rectora del conjunto del Imperio. Con mayor o menor rapidez según la amplitud de los privilegios concedidos, el sistema permite a los jerarcas locales obtener la ciudadanía romana, que será el punto de partida de nuevas aspiraciones políticas. El Sur hispano ofrecerá algunos de los ejemplos más representativos de ello (López Castro, 1995: 228-239).

\section{CONCLUSIONES}

La elaboración de este trabajo permite mostrar la importancia de la escala regional para la comprensión de los procesos de cambio de carácter general. El ejemplo que hemos presentado inserta un espacio concreto, el corredor del Guadiana Menor, en la dinámica más amplia del entorno altoandaluz y en el marco de las comunicaciones siempre necesarias con el Sureste. A través de un eje diacrónico se ha observado cómo este pasillo se convierte en una ruta estable y de gran importancia en el fragmentado panorama político del Ibérico Pleno y Tardío, cuando Tugia supone un enclave fronterizo entre Bastetanos y Oretanos. La canalización del comercio supondrá la fundación de asentamientos en los puntos claves de paso. En yacimientos con esta función, como Castellones de Ceal, la presencia de objetos importados, tanto de zonas limítrofes como alejadas, revela una dedicación comercial que va mas allá de las meras posibilidades de subsistencia que ofrece el entorno.

Cuando el panorama político cambia con la do-

${ }^{23}$ En el curso bajo del río se han localizado dos asentamientos emplazados en terrazas al pie del cauce: La Venta del Barco (topónimo que hace referencia a un vado del río) y Venta de San José. Ambos pueden fecharse en el siglo 1 d.C. En el entorno de este último se documentó un gran silo para el almacenaje de grano. A un tipo de emplazamiento diferente correspondería el yacimiento de Haza de la Cruz, de cronología tardorromana y probablemente más relacionado con aprovechamientos ganaderos o de tráfico comercial .

${ }^{24}$ La epigrafía de Cástulo (Bázquez 1994: 515-527) ofrece excelentes ejemplos de las liberalidades y donaciones que formaban parte de las manifestaciones de poder de esta elite municipal. minación romana, las fronteras anteriores dejan de mantenerse y se puede optar por otros diseños viarios más rentables de cara a la comercialización de excedentes. Esto no implica una desaparición inmediata del modelo anterior, pero sí una progresiva decadencia, ya que el grueso de las mercancías se orienta hacia rutas más fácilmente franqueables. Otras épocas históricas nos revelan una misma respuesta. El Guadiana Menor aparece de nuevo con cierta relevancia en las fuentes medievales cuando vuelve a convertirse en zona fronteriza, primero entre la Cora de Jaén y la Cora de Tudmir (reino de Murcia), y posteriormente como límite por largo tiempo consolidado de la Reconquista (Segura, 1983: 78-79). Por el contrario a partir del siglo XVI este camino no aparece en los repertorios que recogen las principales vías de un reino unificado y cada vez más centralizado, situación que se arrastra hasta nuestros días (Villegas Molina, 1981).

El papel político y económico de canalización comercial condicionará asimismo las estrategias de explotación y usos del suelo. Si durante el período ibérico el oppidum parece configurarse como la única unidad de asentamiento, es evidente que en esta zona existe una planificación a escala territorial, con centros principales que establecen y controlan otros centros secundarios. Éstos cumplen un papel complementario, ligándose a explotaciones específicas, al control de las rutas de paso o simplemente a la colonización de territorios agrícolas alejados del centro principal. Las relaciones clientelares permiten ahora una diversificación de los lazos sociales, más allá de los meramente parentales que parecen dominar en épocas precedentes.

Este esquema, en el que las elites locales van a jugar un papel preponderante, parece prolongarse incluso en los primeros momentos de la dominación romana, cuando en la Alta Andalucía son mantenidas como gestoras de los principales recursos exportables, especialmente los agropecuarios y mineros. Esto permite una cierta fosilización de las estructuras anteriores, aun cuando el marco político y económico global está cambiando con rapidez. El mantenimiento de los esquemas productivos permite pensar en la supervivencia de las relaciones sociales internas entre los grupos ibéricos, ya que la interacción inicial con el ámbito romano se haría a través de los grupos dirigentes. La transformación de los sistemas de dependencia durante esta etapa de cambio será el verdadero núcleo del problema de la romanización.

El paso al modelo municipal romano es básico para comprender el desmantelamiento de las redes anteriores. La ampliación del marco político en el 
que se integran los yacimientos de Andalucía oriental, así como la fundación de nuevos centros y el hecho de que las tierras sean susceptibles de ser ocupadas por pequeños colonos, supone una reorganización profunda del diseño estratégico y de los sistemas de explotación de la tierra. Zonas mantenidas antes como puntos claves de comunicación, son ahora sustituidas por otras rutas más transitables, haciendo inviable el mantenimiento de los centros anteriores, que entran en contradicción con el nuevo modelo político y económico. Éste será el caso del Guadiana Menor, en donde comienzan a documentarse explotaciones más pequeñas en las zonas más abiertas del valle. El nuevo patrón de relaciones, en gran medida aún por definir, no se ajusta ya a los viejos modelos y, en consecuencia, los asentamientos directamente ligados a ellos, como el poblado de los Castellones, dejarán de existir.

\section{BIBLIOGRAFÍA}

Adroher Auroux, A.M., 1987-1988: Cerámica de barniz negro en el Sureste: bases para un análisis geoeconómico. Cuadernos de Prehistoria de la Universidad de Granada 12-13: 187-194.

Almagro Gorbea, M., 1982: Tumbas de cámara y cajas funerarias ibéricas. Su interpretación sociocultural y la delimitación del área ibérica de los bastetanos. Homenaje a Conchita Fernández Chicarro. Ministerio de Cultura. Madrid: 249257.

Almagro Gorbea, M., 1987: El área superficial de las poblaciones ibéricas. Coloquio: Los Asentamientos Ibéricos ante la Romanización. Ministerio de Cultura. Casa de Velázquez. Madrid: 21-33.

Almagro Gorbea, M. (1995): Iconografía numismática hispánica: jinete y cabeza varonil. En M.P. García-Bellido y R. M. Sobral Centeno (eds): La Moneda Hispánica. Ciudad y Territorio. Actas del I Encuentro Peninsular de Numismática Antigua. Anejos del Archivo Español de Arqueología XIV: 53-64.

BLANCO, A., 1959: Excavaciones arqueológicas en la Provincia de Jaén. Boletín del Instituto de Estudios Gienenses. Año VI, $\mathrm{n}^{\circ} 22:$ 89-128.

BLÁzQUEZ, J.M. (1985): Economía y sociedad durante la dinastía Julio-Claudia y Flavia. En Historia de España Antigua II: 379-445. Ed. Cátedra. Madrid.

BlázQuEz, J.M., 1996: Las explotaciones mineras y la romanización de Hispania. En J.M.Blázquez; J. Alvar (ed.): La Romanización de Occidente. Madrid: 179-201.
Blázquez, J.M. y García Gelabert, M.P. 1994: Cástulo, ciudad ibero-romana. Istmo. Madrid.

CABRÉ, J., 1925: Arquitectura hispánica: el sepulcro de Toya . Archivo Español de Arte y Arqueología 1: 73-101.

CABré, J. y Motos, F. 1929: La necrópolis ibérica de Tútugi (Galera, provincia de Granada). Junta Superior de Excavaciones y Antiguedades Mem. $n^{\circ} 25$.

Cabrera, P., 1994: Cádiz y el comercio de productos griegos en Andalucía Occidental durante los siglos V y IV a.C. Trabajos de Prehistoria 51(1): 167-181.

Castro López, M. 1989: De César a Teodosio . En Fernández García coord.): Jaén. Vol. 2: 423-441. Ed. Andalucía. Granada.

ChAPA, T. 1992: Caracterización económica de la Alta Andalucía durante la etapa ibérica plena y tardía. En A. Moure (ed.): Elefantes, ciervos y ovicaprinos. Economía y aprovechamiento del medio en la Prehistoria de España y Portugal. Universidad de Cantabria. Santander: 315-326.

Chapa, T.; Fernández, M.; Pereira, J.; Ruiz, A., 1984: Análisis económico y territorial de Los Castellones de Ceal Jaén). Arqueología Espacial 4: 223-240. Teruel.

Chapa, T.; Pereira, J.; Madrigal, A.; Mayoral, V. e.p.: La Necrópolis Ibérica de Los Castellones de Ceal (Hinojares, Jaén). Consejería de Cultura. Junta de Andalucía. Sevilla.

Chaves, F. 1994: Indigenismo y romanización desde la óptica de las amonedaciones hispanas de la Ulterior. Habis 25: 107-120.

Chaves, F. 1996: Los Tesoros del Sur de Hispania. Conjuntos de denarios y objetos de plata durante los siglos II y I a.C. Fundación El Monte. Sevilla.

Choclán, C. y Castro, M. 1987: Ciudad y Territorio en la Campiña de Jaén. La distribución de los asentamientos durante la época Flavia. Studia Historica-Historia Antigua (I): 145-160.

Domergue, C. 1965: Les Planii et leur activité industrielle en Espagne sous la République. Melánges de la Casa de Velazquez 1: 9-27.

Domergue, C. 1966: Les lingots de plomb romains du Musée Archéologique de Carthagène et du Musée Naval de Madrid. Archivo Español de Arqueología, 39: 41-72.

Domergue, C. 1990: Les mines de la Péninsule Ibérique dans L'Antiquité Romaine. Collection de L'École Francaise de Rome 127. Paris.

Domergue, C.; Liou, B. 1997: L'apparition de normes dans le commerce maritime romain: le cas des métaux et des denrées transportées en amphores. Pallas 46: 11-30. 
Fernández Chicarro, C. 1954: Viaje de prospección arqueológica por el término de Peal de Becerro (Jaén). Revista de Archivos, Bibliotecas y $\mathrm{Mu}$ seos 60 (2): 545-557. Madrid.

FERnÁndez ChicARro, C. 1957: Avance sobre recientes prospecciones arqueológicas en Castellar de Santisteban y Peal de Becerro. Boletín del Instituto de Estudios Giennenses 13: 153-163.

Fernández Rodríguez, M.; García Bueno, C. 1993: La minería romana de época republicana en Sierra Morena: el poblado de Valderrepisa (Fuencaliente, Ciudad Real) . Melánges de la Casa de Velázquez XXIX: 25-50.

Fernández Rodríguez, M; LóPez Fernández, F.J. ; Madrigal Belinchón, A. ; Mayoral Herrera, V. 1994: Aproximación al estudio etnoarqueológico del Guadiana Menor (Jaén). Trabajos de Prehistoria 51 (1): 111-125

García-Bellido, M.P. 1982: Las monedas de Cástulo con escritura indígena. Historia numismática de una ciudad minera. A.N.E. y Univ. de Salamanca. Barcelona.

García-Bellido, M.P. 1986: Nuevos documentos sobre minería y agricultura romanas en Hispania. Archivo Español de Arqueología 59: 13-46.

García-Bellido, M. P.1993: Origen y función del denario ibérico . En Sprachen und Schriften der antiker Mittelmeerraum. Festschrift für Jünger Untermann. Insbruck: 97-123.

García Mora, F. 1994: El conflicto sertoriano y la provincia Hispania Ulterior. En Actas del II Congreso de Historia de Andalucía (Córdoba, 1990), 3; Historia Antigua. Córdoba: 271-286.

Gómez Moreno, M. 1961: La escritura bástulo-turdetana (primitiva hispánica). Revista de Bibliotecas, Archivos y Museos 69.

GonZÁlez Román, C. 1981: Imperialismo y romanización en la Provincia Hispania Ulterior. Estudios de Historia Antigua II. Universidad de Granada.

GonZÁlez RomÁn, C. 1992: La colonia Iulia Gemella Acci y la evolución de la Bastetania. En Conquista romana y modos de intervención en la organización urbana y territorial. Dialoghi di Archeología 1-2: 155-164.

GonZÁlez Román, C. 1994: Control romano y resistencia indígena en los orígenes de la Bética. En Actas del II Congreso de Historia de Andalucía (Córdoba, 1990), 3; Historia Antigua. Córdoba: 131-147.

KEAY, S. J: 1992: The «Romanisation» of Turdetania. Oxford Journal of Archaeology 11 (3): 275-315.

KEAY, S. J., 1995: Innovation and adaptation: the contribution of Rome to urbanism in Iberia. En
Cunliffe, B.; Keay, S.J. (ed): Social Complexity and the Development of Towns in Iberia. From the Copper Age to the Second Century AD. Proceedings of the British Academy 86. Oxford University Press. Oxford: 291-337.

LaCort, P.; Portillo, R. y Stylow, A. 1986: Nuevas inscripciones latinas de Córdoba y su provincia . Faventia 8/1: 69-109.

Lagunas, M.A; Rísquez, C.; Serrano, J.L. 1989: Prospección arqueológica superficial en el curso bajo del río Jandulilla. Anuario Arqueológico de Andalucía 1989-III: 110-115

López Castro, J.L. 1995: Hispania Poena. Los fenicios en la Hispania romana. Ed. Crítica. Barcelona.

Madrigal Belinchón, A. 1997: El ajuar de la cámara funeraria ibérica de Toya (Peal de Becerro, Jaén). Trabajos de Prehistoria 54 (1): 167-181.

MaluQuer, J. 1968: Epigrafía prelatina de la Península Ibérica. Universidad. Barcelona.

Marcos Alonso, C, 1996: Aportación a la circulación de las imitaciones de divisores romano-republicanos en la Península Ibérica. Numisma 237: $199-223$

MARÍN DÍAZ, M. 1988): Emigración, colonización y municipalización en la Hispania republicana. Universidad de Granada.

Marín Díaz, N.; Gener Basallote, J.M. y Pérez CRUZ, M.A. 1993-94: La ciudad ibero-romana de Basti. Florentia Iliberritana 4-5: 323-333.

Mergelina, C. 1944: Tugia. Reseña de unos trabajos. Boletín del Seminario de Estudios de Arte y Arqueología 10: 13-32.

Molinos Molinos, M. et al. en prensa: El Cortijo de El Pajarillo (Huelma, Jaén). Jaén.

Molinos Molinos, M. et al. 1994: Un problema de fronteras en la periferia de Tartessos: Las Calañas de Marmolejo (Jaén). Universidad de Jaén.

Molinos Molinos, M.; Hornos Mata, F.; Choclán SABINA, C. 1986: El poblamiento ibérico en el Alto Guadalquivir. En Iberos. I Jornadas sobre el Mundo Ibérico: 239-257. Consejería de Cultura de la Junta de Andalucía.

Pastor, M.; Carrasco, J.; PAchón, J.A., 1992: Paleoetnología de la Andalucía Oriental (etnogeografía) . En Almagro Gorbea, M.; Ruiz ZapateRO, G. (ed.): Paleoetnología de la Península Ibérica. Complutum 2-3: 119-136.

Pellicer, M.; Schüle, W. 1962: El Cerro del Real. Galera (Granada). Excavaciones Arqueológicas en España 12.

Pereira Sieso, J., 1989: La cerámica ibérica de la Cuenca del Guadalquivir II. Conclusiones. Trabajos de Prehistoria 46: 149-160. 
Pérez Cruz, Ma A. 1996-97: Res Publica Tutugitanorum. Annals de l'Institut d'Estudis Gironins 38: 1601-1612.

PlácIDO, D. 1996: Formas de dependencia en Hispania. En J.Ma. Blázquez y J.Alvar (ed.): La romanización de occidente. Editorial Actas. Madrid: 201-217.

Presedo, F., 1982: La Necrópolis de Baza. Excavaciones Arqueológicas en España 119. Ministerio de Cultura. Madrid.

RodRíGUEZ NEILA, J.F. 1993): Gestón administrativa en las comunidades indígenas hispanas durante la etapa pre-municipal. En J.F. Rodríguez Neila (coord): Actas del I Coloquio de Historia Antigua de Andalucía. Córdoba 1988. Vol.1. Córdoba: 385-413.

RodrígueZ NeILA, J.F. 1993-4: Ciudad y territorio en la provincia romana de la Bética. Florentia Illiberritana 4-5: 445-484.

RodRíGuez NeILA, J.F. 1995: Organización administrativa de las comunidades hispánicas y magistraturas monetales. En M.P. GARCíA-BELLIDO y R. M. Sobral Centeno (ed.): La Moneda Hispánica. Ciudad y Territorio. Actas del I Encuentro Peninsular de Numismática Antigua. Anejos de Archivo Español de Arqueología XIV: 261275.

Ruiz Rodríguez, A. 1978: Los pueblos ibéricos del Alto Guadalquivir. Cuadernos de Prehistoria de la Universidad de Granada 3: 255-284.

Ruiz Rodríguez, A. y Molinos Molinos, M. 1993a: Los Iberos. Análisis arqueológico de un proceso histórico. Ed. Crítica. Barcelona.
Ruiz Rodriguez, A. y Molinos Molinos, M., 1993b: Proyecto: Poblamiento Ibérico en la Campiña de Jaén. Investigaciones Arqueológicas en Andalucía 1985-1992. Huelva: 543-578.

Ruiz Rodríguez, A.; Molinos, M.; López, J.; CresPO, J.; Choclán, C. y Hornos, F., 1983: El horizonte ibérico antiguo del Cerro de la Coronilla, Cazalilla (Jaén). Cuadernos de Prehistoria de la Universidad de Granada 8: 251-300

Ruiz Rodríguez, A.; Rísquez Cuenca, C.; Hornos MatA, F., 1992: Las necrópolis ibéricas de la Alta Andalucía. Congreso de Arqueología Ibérica: Las Necrópolis. Universidad Autónoma de Madrid. Comunidad de Madrid: 397-430.

Segura, C. 1983: La formación del pueblo andaluz. Los repartimientos medievales. Istmo. Madrid.

Sillières, P. 1990: Les Voies de Communication de L'Hispanie Meridionale. Publications du Centre Pierre Paris. Paris.

Solana SÁInz, J.M. 1989: Colonización y Municipalización bajo César y Augusto: Hispania Citerior. En A.A.V.V.: Aspectos de la Colonización y $\mathrm{Mu}$ nicipalización de Hispania. Museo Nacional de Arte Romano. Mérida: 71-107.

VICENT, J. 1992: Fundamentos teórico-metodológicos para un programa de investigación arqueogeográfica. En P. LóPEz (ed.): El cambio cultural en la comarca noroeste de Murcia. CSIC. Madrid.: 31-118.

Villegas Molina, F. 1981: El medio natural y las comunicaciones terrestres en Andalucía Oriental. En Estudios de Geografía. Homenaje a Alfredo Floristán. Pamplona: 461-484. 